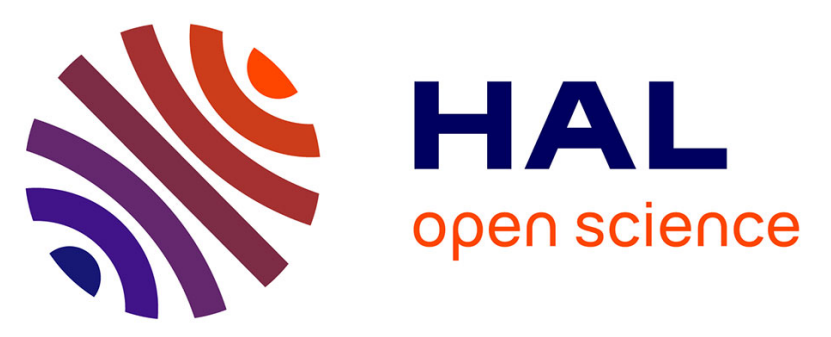

\title{
PERFORMANCE OF MOX GAS SENSORS OBTAINED BY MIXING P-TYPE AND N- TYPE METAL OXIDES FOR RELIABLE INDOOR AIR QUALITY MONITORING
}

Aymen Sendi, Pierre Fau, Myrtil L. Kahn, Katia Fajerwerg, Vincent Bley, Chaabane Talhi, Frédéric Blanc, Philippe Menini

\section{To cite this version:}

Aymen Sendi, Pierre Fau, Myrtil L. Kahn, Katia Fajerwerg, Vincent Bley, et al.. PERFORMANCE OF MOX GAS SENSORS OBTAINED BY MIXING P-TYPE AND N- TYPE METAL OXIDES FOR RELIABLE INDOOR AIR QUALITY MONITORING. Transducers 2019, Jun 2019, Berlin, Germany. 10.1109/TRANSDUCERS.2019.8808186 . hal-02172225

\section{HAL Id: hal-02172225 \\ https://hal.laas.fr/hal-02172225}

Submitted on 15 Jul 2019

HAL is a multi-disciplinary open access archive for the deposit and dissemination of scientific research documents, whether they are published or not. The documents may come from teaching and research institutions in France or abroad, or from public or private research centers.
L'archive ouverte pluridisciplinaire HAL, est destinée au dépôt et à la diffusion de documents scientifiques de niveau recherche, publiés ou non, émanant des établissements d'enseignement et de recherche français ou étrangers, des laboratoires publics ou privés. 


\title{
PERFORMANCE OF MOX GAS SENSORS OBTAINED BY MIXING P-TYPE AND N- TYPE METAL OXIDES FOR RELIABLE INDOOR AIR QUALITY MONITORING
}

\author{
Aymen Sendi ${ }^{1}$, Pierre Fau ${ }^{2}$, Myrtil L. Kahn ${ }^{2}$,Katia Fajerwerg ${ }^{2}$, Vincent Bley ${ }^{3}$, Chaabane Talhi ${ }^{1}$, \\ Frederic Blanc ${ }^{1}$ and Philippe Menini ${ }^{1}$ \\ ${ }^{1}$ LAAS-CNRS, University of Toulouse, CNRS, Toulouse, FRANCE \\ ${ }^{2}$ LCC-CNRS, University of Toulouse, CNRS, Toulouse, FRANCE \\ ${ }^{3}$ LAPLACE, University of Toulouse, UT3 Paul Sabatier, Toulouse, FRANCE.
}

\section{Novelty}

In this work, we study the effect of n-p heterojunctions in metal oxides (MOX) gas sensors, and particularly on their gas sensitivity and relative humidity dependence for indoor air quality applications. This effect depends on the relative proportion of MOX in the mixture. This study was achieved in order to build a MOX gas sensor that overcomes the effects of humidity variations and to improve the overall sensitivity of MOS gas sensors.

\section{Background}

Indoor air quality is major health concern in our societies but European recommendations (directive 2008/50/EC) will be still difficult to fulfill without the help of simple and efficient air quality monitoring systems. MOX gas sensors have proven their interest for the air quality monitoring in open air or indoor areas [1]. The main drawback of theses sensors concerns their stability over time and lack of selectivity among mixtures of gases as well as in variable humidity environment. While a great attention has been focused on n-type semiconducting oxides, few studies have been devoted to the p-type gas sensors. Among p-type oxide semiconductors, single phase, or $\mathrm{CuO}$ as part of heterojunction sensors, have demonstrated considerable potential for detection of gases such $\mathrm{C}_{2} \mathrm{H}_{5} \mathrm{OH}, \mathrm{NO}_{2}, \mathrm{H}_{2} \mathrm{~S}, \mathrm{H}_{2}$, $\mathrm{CO}$ and $\mathrm{NH}_{3}$ [2]. Some of these sensors exhibited interesting selectivity properties towards investigated gases.

\section{Description of the New Method}

In order to increase the sensitivity and the selectivity of semi-conducting gas sensors, $\mathrm{SnO}_{2}$, $\mathrm{WO}_{3}, \mathrm{CuO}$ and $\mathrm{ZnO}$ nanopowders of this study have been synthesized by a metalorganic approach and mixed in binary or ternary blends in order to prepare efficient sensitive layers integrated on silicon substrates. The mixture of n-type and p-type metal oxides have been used to modify the response gas sensor [3], but there is still a lack of knowledge about the role of n-p heterojunction to overcome the effect of the hygrometry changes. In this work, the optimum blending of different metal oxides (n-type and p-type) is achieved by mixing and grinding the nanoparticles previously suspended in an organic solvent. Then the mixed metal oxides have been prepared in the form of a screen-printing paste in order to facilitate their deposition on silicon micro hotplates [4]. Gas sensors have been realized with nanostructured $\mathrm{SnO}_{2}$ (Fig. 1) and a blend (Fig. 2) composed by $75 \%$ in volume of $\mathrm{CuO}$ and $25 \%$ of $\mathrm{ZnO}$ (Table 1).

With an experimental set-up, we applied a gas injection protocol (Fig. 3). All injections with the reactive gas concentrations are summarized in Table 2. Another preparation mixture was set up where $\mathrm{WO}_{3}$ particles (fig. 4) mixed with various amounts of nanosized $\mathrm{SnO}_{2}$ or $\mathrm{CuO}$ were used. The performances (sensitivity, stability) of the gas sensors are presented and compared with simple MOX sensors.

\section{$\underline{\text { Experimental Results }}$}

In Figure 5 we present the result of $\mathrm{SnO}_{2}$. The sensor sensitivity decreases in dry air, and the resistance baseline is different between dry and humid air. This suggests that the humidity influence is prominent for a single metal oxide composition as $\mathrm{SnO}_{2}$.

In Figure 6 we show the effect of mixing 25\% mass of $\mathrm{SnO}_{2}$ with $75 \%$ mass of a binary $\mathrm{CuO} / \mathrm{ZnO}$ blend. The sensor response sensitivity is lowered in dry and humid air but the baseline has only slightly changed. In Figure 7 we present the result of the ternary mixture made of $\mathrm{SnO}_{2}(50 \%)$ and $\mathrm{CuO} / \mathrm{ZnO}(50 \%)$. The resistance baseline remains unchanged between dry and humid air conditions, so that it overcomes the effect of humidity, and thus improves the gas 
sensitivity in humid air conditions (30\% RH).

The interest of $\mathrm{p}-\mathrm{n}$ junctions in gas sensing sensitivity and humidity variation for indoor air quality are discussed and justified.

\section{Word Count: 600}

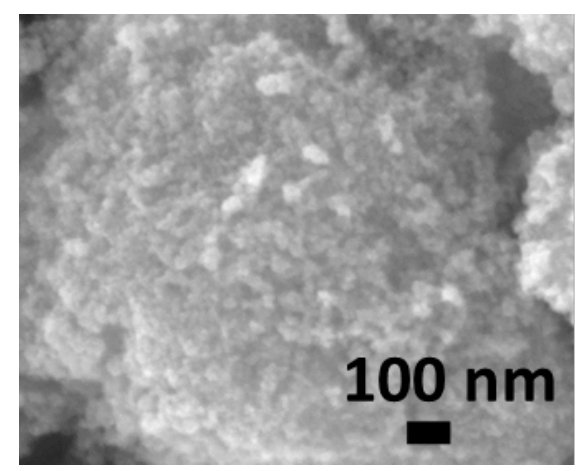

Figure 1: SEM image of nanosized $\mathrm{SnO}_{2}$ sensitive layer-100nm

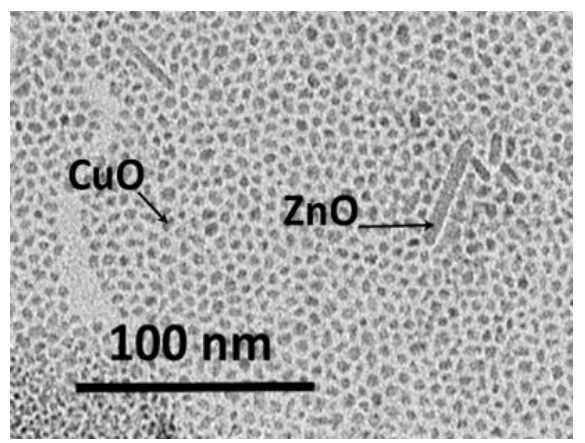

Figure 2: TEM image of $\mathrm{CuO} 75 \% / \mathrm{ZnO} 25 \%$ blend -

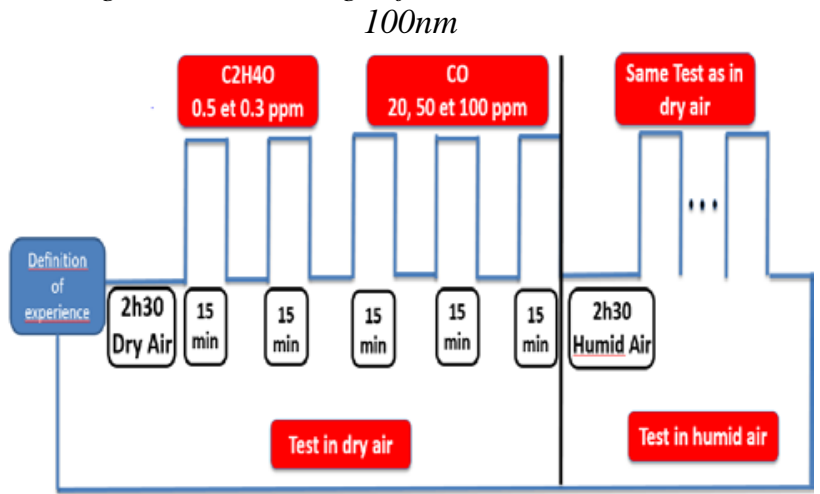

Figure 3: Synoptic representative of gas injections and their concentrations in dry and humid air.

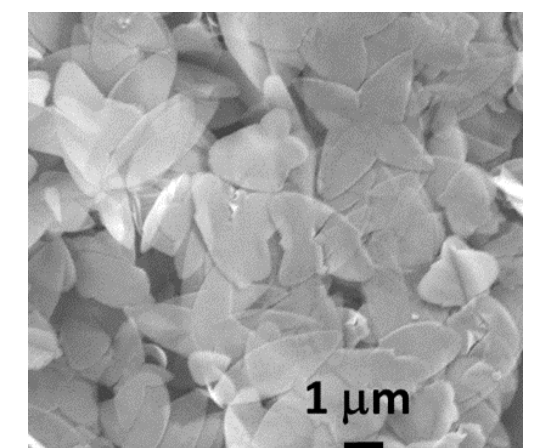

Figure 4: SEM image of $\mathrm{WO}_{3}$ sensitive layer

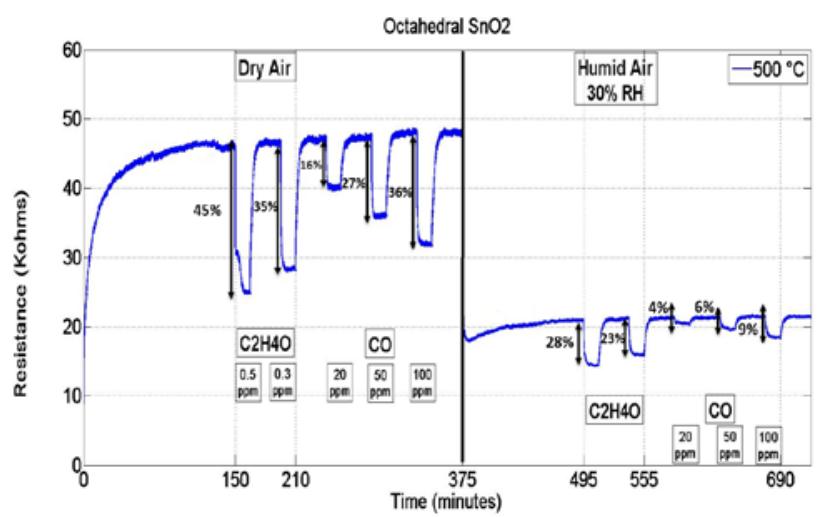

Figure 5: Responses of gas sensor at $500^{\circ} \mathrm{C}$ for the $\mathrm{SnO}_{2}$ in dry and humid air.

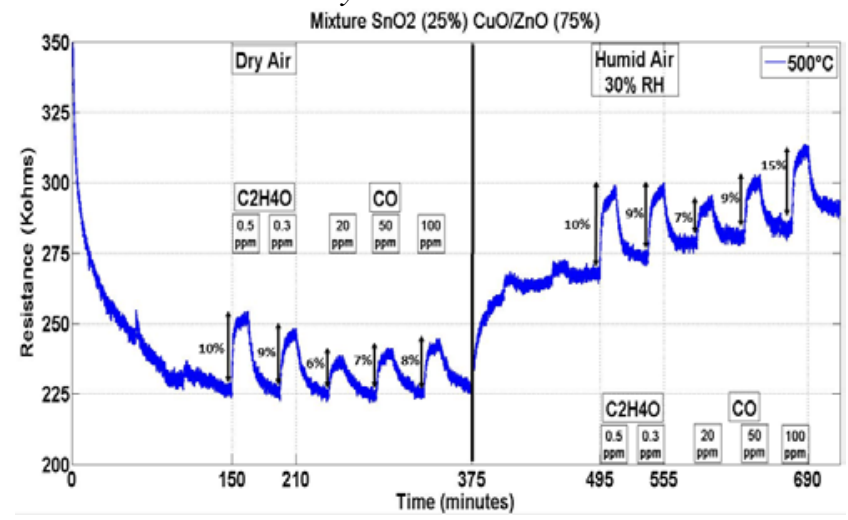

Figure 6: Responses of gas sensor at $500^{\circ} \mathrm{C}$ for the ternary mixture $25 \% \mathrm{SnO}_{2}$ and $75 \%$ of $\mathrm{CuO} / \mathrm{ZnO}$ in dry



Figure 7: Responses of gas sensor at $500^{\circ} \mathrm{C}$ for the 
ternary mixture $50 \% \mathrm{SnO}_{2}$ and $50 \%$ of $\mathrm{CuO} / \mathrm{ZnO}$ in dry and humid air.

Table 1: The different sensors and their composition

\begin{tabular}{|c|c|c|}
\hline Sensors & Type & MOX Blend (\% masse) \\
\hline Sensor 1 & Single & $\mathrm{SnO}_{2} 100 \%$ \\
\hline Sensor 2 & $\begin{array}{l}\text { Ternary } \\
\text { mixture }\end{array}$ & $\begin{array}{l}25 \% \mathrm{SnO}_{2} \text { and } 75 \% \text { of } \\
\mathrm{CuO} / \mathrm{ZnO}\end{array}$ \\
\hline Sensor 3 & $\begin{array}{l}\text { Ternary } \\
\text { mixture }\end{array}$ & $\begin{array}{c}50 \% \mathrm{SnO}_{2} \text { and } 50 \% \text { of } \\
\mathrm{CuO} / \mathrm{ZnO}\end{array}$ \\
\hline
\end{tabular}

Table 2: Injected gas concentrations

\begin{tabular}{|c|c|}
\hline Gas & Concentrations \\
\hline Acetaldehyde & $500 \mathrm{ppb}$ \\
\cline { 2 - 2 } & $300 \mathrm{ppb}$ \\
\hline Carbon Monoxide & $20 \mathrm{ppm}$ \\
\cline { 2 - 2 } & $50 \mathrm{ppm}$ \\
\cline { 2 - 2 } & $100 \mathrm{ppm}$ \\
\hline
\end{tabular}

\section{References}

1. Jońca, J.; Ryzhikov, A.; Palussière, S.; Esvan, J.; Fajerwerg, K.; Menini, P.; Kahn, M.L.; Fau, P. Chem. Phys. Chem. "Organometallic Synthesis of $\mathrm{CuO}$ Nanoparticles: Application in Low-Temperature CO Detection", 2017, 18, 2658-2665.

2. Y. Chen; Z. Shen; Q. Jia; J. Zhao; Z. Zhao; H. Ji. RSC Adv. "A CuO-ZnO nanostructured $p-n$ junction sensor for enhanced $N$-butanol detection”, (2016), 6, 2504

3. A. Sendi, P. Menini, M. Kahn, K. Fajerwerg, P. Fau. "Effect of Nanostructured octahedral $\mathrm{SnO}_{2}$ added with a binary mixture P-type and N-type metal oxide on CO detection". In Proceedings of the 32th Eurosensors Conference, Eurosensors 2018, Graz, Autrich, September 912, 2018; 2, 986.

4. Dufour, N.; Chapelle, A.; Mesnilgrente, F.; Conedera, V.; Menini, P. "Technological improvements of a metal oxide gas multi-sensor based on a micro-hotplate structure and inkjet deposition for an automotive air quality sensor application". In Proceedings of the 25th Micromechanics and Microsystems Europe Workshop, MME 2014, Istanbul, Turkey, August 31- September 3, 2014; 4p. 